\author{
M. Petrova ${ }^{1}$, E.A. Uteubayeva ${ }^{2}$, T.A. Kokhanover ${ }^{2 *}$ \\ ${ }^{1}$ ISMA University, Riga, Latvia; \\ ${ }^{2}$ Karagandy University of the name of academician E.A. Buketov, Kazakhstan \\ (E-mail:ztan@mail.ru)
}

\title{
Didactic approach to the process of communicative competence formation
}

\begin{abstract}
Article is devoted to studying of the didactic approach to teaching foreign languages. One of the key elements of foreign languages teaching is didactic approach, which organize and manage the process of teaching and is aimed at achieving the best result. It is very important to chose the appropriate didactic principles and organize its activity in pedagogical process. As a result of analyses of Russian and foreign methodologist in the article we made the attempt to elicit and prove the main and effective principles of didactic approach to improve the communicative competence of the learners in the conditions of trilingual education.
\end{abstract}

Keywords: didactic approach, principles, communicative competence, foreign languageteaching, activity, integrated teaching, individualization, communicative approach.

\section{Introduction}

In order to define didactic conditions, it is necessary to consider the principles of teaching foreign languages in general. In general pedagogy, the principle of learning is the main provisions that determine the nature of the learning process, which are formulated on the basis of the chosen direction and approaches corresponding to this direction. Well-defined teaching principles help to decide what, how and what content to choose, what materials and techniques to use. The formation of communicative competence is based on lever structure of the language [1], thus it demand the choice of appropriate didactic principles for teaching.

By the conditions of foreign language teaching we will understand the circumstances under which teaching takes place. The principles of teaching determine the content, organizational forms and methods of the educational process in accordance with its goals and laws.

The principles of teaching characterize the methods of using laws and laws in accordance with the intended goals. The principles of learning by their origin are a theoretical generalization of pedagogical practice. They are objective, arise from the experience of practical activity. The Principles are therefore guidelines that govern activities in the process of educating people. They cover all aspects of the learning process. At the same time, the principles are subjective in nature, as they are reflected in the teacher's mind in different ways, with varying degrees of completeness and accuracy.

Misunderstanding or ignorance of learning principles, inability to follow their requirements do not cancel their existence, but make the learning process unscientific, ineffective, contradictory. Adherence to teaching principles is the most important condition for the effectiveness of the teaching process, an indicator of the teacher's pedagogical culture.

\section{Methods}

The history of the development of school and pedagogy shows how, under the influence of changing the requirements of life, the principles of learning change, that is, the principles of learning are historical in nature [2]. Some principles disappear, others appear. This suggests that didactics should be sensitive to changes in society's requirements for education and respond to them in a timely manner, that is, to build a system of teaching principles that correctly indicates the path to achieving the goal of learning.

Scientists have long paid great attention to the justification of the principles of learning. The first attempts in this direction were made by J.A. Komensky, J. -Z. Russo, I.G. Pestalozzi. Ya. A. Komensky formulated and substantiated such principles of learning as the principle of nature, strength, accessibility, systematics, etc.

K.D. Ushinsky attached great importance to the principles of teaching [3]. He most fully disclosed didactic principles:

- Education should be accessible to students, not overly difficult and not too easy;

- Education should in every way develop children's autonomy, activity, initiative;

\footnotetext{
${ }^{*}$ Corresponding author's E-mail: ztan@mail.ru
} 
- Order and systematic - one of the main conditions for success in learning, the school should give sufficiently deep and thorough knowledge;

- Education should be conducted in a natural manner, in accordance with the psychological characteristics of students;

- Teaching of every subject must certainly go in such a way that the pupil has exactly as much work to overcome as young forces can.

The wording and number of principles changed in the following decades (Yu. K. Babansky, M.A. Danilov, B.P. Esipov, T.A. Ilyina, M.N. Skatkin, G.I. Schukin and others). This is the result of the fact that objective laws of the pedagogical process have not yet been fully discovered.

In classical didactics, the following didactic principles are considered the most widely recognized:

- Science;

- Visibility;

- Accessibility;

- Consciousness and activity;

- Systematics and sequences;

- Strength, connection of theory with practice.

\section{Results and discussion}

The foreign methodology for teaching foreign languages is based on the following fundamental principles of didactics:

- the principle of mindfulness;

- communicative approach;

- differentiated and integrated teaching;

- activities;

- visuality;

- accessibility and durability;

- individualization;

- sequence;

- systematic;

- heuristics, etc.

The principle of mindfulness

This is one of the leading principles, because conscious learning plays an important role in the acquisition of language, expands the intellectual capabilities of students, helps to understand new concepts and express new ideas in the target language. This principle also implies understanding the language phenomena of students through the means of communication. The principle of a conscious approach ensures a purposeful perception and understanding of the material, its creative understanding and extraction of information from the student with a certain degree of automation.

In foreign language teaching, it is sometimes wise to help students learn language rules rather than wait for them to derive these rules through speech activity. The teacher's task is not to put this hard work on the student's shoulders, but to facilitate the process of teaching the rules and practice it in real situations.

A conscious approach to teaching foreign languages involves the use of a native language, when this helps students to better understand certain grammatical rules. Mastering a foreign language means moving to thinking in a second language [4]. To do this, you need to acquire the ability to establish direct connections between concepts and the means of expressing them in the target language. Visual means and verbal context invariably help to establish a connection between what a student says, sees, reads and displays meaning.

Initially, when a student learns a foreign language, the words of that language are often associated with the words of the native language. However, thanks to constant practice, this connection of the mother tongue with the target language regains the consciousness of the student directly in connection with the concepts they express.

Mastering a foreign language means formulating thoughts in that language.

Thus, it can be concluded that in order to master a foreign language, students must have a lot of practice in four skills: listening, speaking, reading and writing. As for the mother tongue, we cannot completely eliminate it. We must scrupulously use it as a means of learning whenever it helps students to acquire knowledge and achieve a goal in the shortest possible time, that is, to develop the necessary habits and skills. 
Care should be taken when transferring pronunciation habits and grammatical structures of one language to another. When learning English, Russian and Kazakh-speaking students often make errors in word order, grammar and spelling of statements. The best way to overcome interference is some comparison of language phenomena that show the difference in languages.

The best way to overcome interference is some comparison of language phenomena showing similarities, distinguishing features, areas of similarity and retreat, as well as constant practice that helps overcome interference in the development of students' habits and skills.

Principle of activity

The didactic principle of activity involves the constant accumulation of knowledge and the active participation of students in the teaching process. In the process of teaching English, we usually distinguish between intellectual, emotional and speech activities, which, if combined, provide favorable conditions for mastering the language. Intellectual activity can be obtained through guesses, issues of solving problems, reading texts with their subsequent interpretation, etc. Emotional activity occurs when students are satisfied with the work they do, when they enjoy learning a foreign language and like the way they teach. Speech activity appears during oral communication and is largely due to the intellectual and emotional activity that «feeds» it. To intensify activities, students' learning activities must be intensified. This can be achieved by group, pair and team work (discussion of the book, role-playing games, holding a press conference, etc.).

In the teaching of foreign languages, the principle of activity is implemented through the following provisions:

1. From the very beginning, students should be taught to think not in their native language, but in a foreign language.

2. In the early stages and beyond, the approach to foreign language education should be first and foremost oral.

3. Students should be able to speak, act and comment on their actions. Here you can recommend the method of full physical response (TPR).

4. Throughout the course of study, an inductive approach should be taken: practice precedes theory, since theory is active if applied in practice.

5. Group and paired forms of work should be encouraged, as they allow all students to participate actively in classroom work.

In addition to the above-mentioned methods, the teacher should use general didactic recommendations to ensure activity:

1. The teacher should not correct the student's mistakes if the student can do it himself.

2. In individual interviews, the teacher should ask questions not to individual students, but to the whole class in order to attract their attention and ensure their active participation.

3. The teacher must comment on the student's assessments and always find words of praise.

4. Prepare students for self-study.

5. Activity depends largely on interest. Thus, the interest of students should be maintained by telling them about the many opportunities offered by language learning.

The above-mentioned principle of activity suggests the following:

1. A heuristic approach to foreign language teachingwill stimulate students' intellectual activity.

2. The interest of students should be supported by the correct organization of education, the use of targeted educational materials to incite positive motivation of students.

3. Both individual and collective forms of work should be used to ensure the activity and collective spirit of students.

Principle of differentiated and integrated teaching

Each type of speech activity is characterized by its own set of grammatical structures, rules and lexical material. Therefore, we must distinguish between teaching speech and writing; teaching in audio and speech; teaching reading and writing; teaching prepared and unprepared speech, etc. The implementation of this principle is reflected in instructional methodological sets (IMS), which provide «software» for each activity. Readers and periodicals are used to acquire reading skills. Grammar books, handbooks and guides on patterns and use are recommended for acquisition of grammar skills.

Psychological research supports the idea of the relationship and interaction between activities, and these relationships are profound. Therefore, all speech activities should be considered as interrelated parts of the communication process and taken into account in the formation of the communication competence of the student. 
In order to implement the principle of differentiated and integrated treatment, the following teaching strategies could be recommended:

1. The lesson should be conducted in a foreign language and should be addressed to the mother tongue only if absolutely necessary. In teaching, you must use authentic sources to teach auditing and reading skills.

2. When teaching speech, remember that the speech of students is correct, logical, developed, variable and relevant to the topic of discussion. Use opening phrases (gambits), elliptical sentences.

3. When teaching reading, such learning strategies as reading aloud, silent reading, expressive reading, etc. are distinguished. Help students with tips to guess the meaning, draw conclusions and draw conclusions.

4. Teach students to use writing as a means and purpose of foreign language teaching, that is, to learn educational materials and master speech and reading.

The teaching process can also be carried out in an integrated manner - all activities - hearing, speech, reading and writing develop simultaneously in relation to their interaction.

Principle of Visuality

The principle of visualization or postensive principle is implemented in direct and visual modes of semantization or explanation of values, that is, in the demonstration and naming by the teacher of subjects, pictures and actions from which students derive the meanings of the words and expressions used. Visuals in the foreign language teaching methodology create favorable conditions for sensual perception and bring another reality to the instructive and educational process. The principle of visuality is considered one of the main methodological principles, especially at a time when teaching has practical goals. The implementation of visual aids develops speech habits in students and enhances the emotional influence of visual perception. Most teachers consider it necessary to use oral and visual means in one form or another in order to help students through imagination gain experience that is inaccessible to classes.

The visuals used in foreign language teaching have two forms:

1. material or ostensive, consisting of a demonstration of objects and actions;

2. graphic, consisting of paintings, tables, charts, charts, etc.

Visual or ostensive agents play an important role in foreign language teaching. Thinking skills are formed and developed by listening to native speakers or authentic recorded materials. Visual props such as texts or illustrations can complement oral visuals.

The formation of habits and skills of connected speech is almost impossible without the widespread use of vision, which helps to model the communicative situation, stimulates monological and dialogue speech.

The development of reading skills can also be achieved through oral and visual tutorials. Students listen to the tape and try to present objects, pictures and situations related to the text. Most unsuccessful language learning is due to a failure of imagination. One failure is the inability of the students' imagination to understand that words alone may not be enough to carry the student in the situations in which he is trying to bring him. Another setback is that the imagination of disciples cannot create or present the situation in their minds that these words are intended to create for them.

Not enough teachers are aware of the need for creative use of visual aids. That is, they use objects and situations shown in a picture, film, video or other visual representation of reality, as if they were actual objects and situations themselves. But even the best and clearest representation remains a representation; and it must be connected with or based on the experience of reality, some efforts of imagination, however insignificant. A teacher can help students make such efforts by reminding them of similar situations from their own experience and showing them examples.

The above suggests the following conclusions:

1. When teaching a foreign language, it is necessary to use auditory materials (tape recorders, television, video) to provide an understanding of listening.

2. Use audiovisual materials and encourage students to work with them in the language laboratory and independently at home.

3. Make extensive use of visual materials; choose bright drawings, illustrations in speech teaching.

4. Compile situations using verbal and non-verbal means, taking into account linguistic and psychological factors.

Principle of accessibility

In the teaching of foreign languages, this principle is implemented in accordance with the strategies for teaching the abilities of students so that they do not experience insurmountable difficulties. Educational materials must meet the requirements of language and psychological factors: 
1. correspond to the age and mental abilities of students; be neither difficult nor easy;

2. Have an appropriate assessment;

3. be heuristic in shape and structure;

4. be represented in such a way that pupils must solve one problem at a time.

Educational materials, their organization ensure accessibility in foreign language teaching and methods used in lessons and outside school hours. Accessibility involves adequate presentation speed, qualitative assimilation, speed of progress in the formation of speech habits and skills.

Principle of durability

This principle is of particular importance in foreign language teaching, since it is largely associated with the constant growth of language and speech units, words, phrases, idioms, cliches, which must be stored and stored in the memory of students so that students can use them in understanding, speech, reading and writing. Strong and long-term learning, especially in foreign language learning, can be achieved by:

1. content of the material under study; awareness of its importance and the need for communication and reading;

2. the presentation of the new material should be bright, bright and lively; this leads to living images, corresponding associations (perception has an emotional effect on students); they must resort to abstract thinking

3. a lot of repetitive work, supplemented by assimilation, revision and subsequent practice, when visual, aural, kinesthetic and motor analyzers work;

4. this material should be used individually and creatively to solve communicative problems in speech, reading and writing;

5. systematic control of assimilable material helps to keep it in the memory of pupils;

6. revision of the material will be more effective if it is repeatedly presented in a new verbal context, new visual aids and various types of exercises will be used.

Principle of individualization

This principle considers specific features of the pupil, his knowledge, what he knows spheres of his interests, etc., i.e. informative styles. Cognitive styles were defined as characteristic mental and psychological behavior models which «serve as rather stable indicators of how pupils perceive, interact and react to the teaching environment» [4].

Therefore, cognitive styles can be considered as predisposition to concrete ways of approach to teaching and are closely connected with types of the personality. Differences in cognitive styles of people reflect various ways of response of people to teaching situations [5]. The teacher should deal with a wide range of pupils: extroverts (who have the greatest satisfaction from social contacts with other people), introverts (who are egocentric, like to be alone with the dreams and thoughts), deductive (rational and logical types of pupils who like the formulated rules), inductive (who induce rules on examples), etc.

Some pupils can cope easily and flexibly, others require bigger attention and a rigid hand, and the third prefer a certain degree of freedom in the choice of a way of teaching. Therefore, the teacher needs knowledge of psychology for realization of the principle of individual approach to the organization for teaching and successful management of him.

\section{Conclusion}

Considering the peculiarities of foreign languages teaching in the conditions of trilingual education in Kazakhstan we propose the following principles of didactic approach to be actual for developing of communicative competence:

1. consciousness;

2. communicative approach;

3. differentiated and integrated teaching;

4. visuality;

5. accessibility and durability;

6. individualization;

7. sequence.

These principles coordinate the content, organizational forms and methods of the educational process in accordance with foreign language teaching goals. The didactic approach based on these principles is able to provide the qualified communicative competence formation. 


\title{
References
}

2001.

Common European Framework of Reference Learning, Teaching, Assessment. — Cambridge: Cambridge University Press,

2 Сафонова В.В. Коммуникативная компетенция: современные подходы к многоуровневому описанию в методических целях/ В.В. Сафонова. - М.: Изд-во НИЦ «Еврошкола», 2004. - С. 13-44.

3 Сысоев П.В. Язык и культура: в поисках нового направления в преподавании культуры страны изучаемого языка / П.В. Сысоев // Иностранный язык в школе. - 2001. - № 4. - С. 12-15.

4 Хомский Н. Язык и мышление / Н. Хомский. - М.: Изд-во МГУ, 1972. - 123 с.

5 Кобзева Н.А. Коммуникативная компетенция как базисная категория современной теории и практики обучения иностранному языку / Н.А. Кобзева // Молодой ученый. — 2011. — № 3. — Т.2. — С. 118-121.

\author{
М. Петрова, Э.А. Утеубаева, Т.А. Кохановер
}

\section{Коммуникативтік кұзыреттілікті қалыптастыру процесінің дидактикалық шарттары}

\begin{abstract}
Мақала шет тілдерін оқыту процесінің дидактикалық шарттарын зерттеуге арналған. Сонымен, шет тілін оқытудың негізгі элементтерінің бірі - оқу процесін ұйымдастыратын және басқаратын және оку мақсатына жетуге бағытталған дидактикалық тәсіл. Шетел тілін оқыту процесінде дидактикалық принциптерді таңдау және олардың жұмысын ұйымдастыру өте маңызды. Ресейлік және шетелдік әдіскерлердің еңбектерін талдау нәтижесінде мақалада үштілді білім беру жағдайында шет тілдерін оқытудың басты мақсатына - коммуникативті құзыреттілікті қалыптастыруға бағытталған негізгі және тиімді дидактикалық принциптер көрсетілген.
\end{abstract}

Кілт сөздер: дидактикалық тәсіл, принциптер, коммуникативті құзыреттілік, шет тілдерін оқыту, коммуникативті тәсіл, интегралды тәсіл, іс-әрекет, дараландыру.

\section{М. Петрова, Э.А. Утеубаева, Т.А. Кохановер \\ Дидактические условия процесса формирования коммуникативной компетенции}

\begin{abstract}
Статья посвящена изучению дидактических условий процесса обучения иностранным языкам. Так, одним из ключевых элементов иноязычного обучения является дидактический подход, который организует, управляет процессом обучения и направлен на достижение цели обучения. В процессе обучения иностранному языку очень важно выбрать дидактические принципы и организовать их функционирование. В результате анализа работ российских и зарубежных методистов авторами выделены основные и эффективные дидактические принципы, направленные на достижение основной цели обучения иностранным языкам в условиях трехъязычного образования - формирование коммуникативной компетенции.
\end{abstract}

Ключевые слова: дидактический подход, принципы, коммуникативная компетенция, обучение иностранным языкам, коммуникативный подход, интегрированный подход, деятельность, индивидуализация.

\section{References}

2001.

Common European Framework of Reference Learning, Teaching, Assessment. — Cambridge: Cambridge University Press,

2 Safonova, V.V. (2004). Kommunikativnaia kompetentsiia: sovremennye podkhody $\mathrm{k}$ mnohourovnevomu opisaniiu v metodicheskikh tseliakh [Communicative competence; modern approaches to the multilevel description in methodical purposes] Moscow: Izdatelstvo NITS «Evroshkola» [in Russian].

3 Sysoev, P.V. (2001). Yazyk i kultura: v poiskakh novoho napravleniia v prepodavanii kultury strany izuchaemoho yazyka [Language and culture: in search of the new direction in teaching culture of the country of the learned language] IYaSh, 4, 12-18 [in Russian].

4 Chomsky, N. (1972). Yazyk i myshlenie [Language and thinking]. Moscow: Izdatelstvo Moskovskoho universiteta [in Russian].

5 Kobzeva, N.A. (2011). Kommunikativnaia kompetentsiia kak bazisnaia katehoriia sovremennoi teorii i praktiki obucheniia inostrannomu yazyku 「Communicative competence as basic category of the modern theory and practice of training in a foreign language] Molodoi uchenyi, 2, 118-121 [in Russian]. 